\title{
Analisis Kebijakan Pengelolaan Hutan Pendidikan: Studi Kasus Hutan Pendidikan Bengo-Bengo Universitas Hasanuddin
}

\author{
Adrayanti Sabar ${ }^{1, *}$, Yusran Yusran $^{1}$ \\ ${ }^{1}$ Staf Pengajar Fakultas Kehutanan, Universitas Hasanuddin, Makassar Hp.085255810180; \\ *E-mail: adrayantisabar@gmail.com
}

\begin{abstract}
Forest Education as one of forest area with the special purpose for the research and development, education and training and religion and culture. Forest Education Hasanuddin University is used as a vehicle for the community, especially students and researchers to study forests and interrelationships between components of the ecosystem. In the implementation of Forest Education activity does not occur a bit of intersection between stakeholders in the management. This research was conducted in Bengo-Bengo Forest Education, Hasanuddin University, through literature study and secondary data analysis. This study aims to examine policies and regulations related to the management of forest areas with a specific purpose, especially forest education. More specifically, this study aims to (i) identify laws and regulations governing directly or indirectly forest education, from central to local levels, (ii) reviewing policies and regulations, including reviewing the consistency and synchronization of those policies, and (iii) recommend the forest management education policy
\end{abstract}

Keywords: forest policy; forest management; forest education DOI: http://dx.doi.org/10.24259/jhm.v9i2.2976

\section{PENDAHULUAN}

Kebijakan pengelolaan kehutanan masyarakat di kabupaten Maros diatur dalam peraturan daerah nomor 5 tahun 2009. Kebijakan ini sangat penting karena kondisi Maros yang merupakan wilayah pengunungan dan terdapat banyak hutan (Pauzi, 2014). Hutan Bengo-bengo dijadikan sebagai hutan pendidikan Universitas Hasanuddin sejak tanggal 31 Maret 1980 dengan luas areal 1300 ha. Hutan Pendidikan Unhas merupakan hutan yang diperuntukkan untuk kegiatan praktek, penelitian, pelatihan, pengabdian kepada masyarakat dan kerjasama penelitian baik dalam maupun luar negeri. Kawasan Hutan Pendidikan Universitas Hasanuddin ini terletak di Desa Limapocoe, Kecamatan Cenrana, Kab. Maros, Sulawesi Selatan. Secara administratif berada di tiga kecamatan yaitu Kecamatan Cenrana, Kecamatan Camba, dan Kecamatan Mallawa.

Hutan pendidikan bengo-bengo merupakan kawasan hutan dengan tujuan khusus yang diatur dalam Pasal 8 Undang-undang Nomor 41 Tahun 1999 mengenai penetapan kawasan hutan dengan tujuan khusus, juga pada Pasal 34 Undang-undang No. 41 Tahun 1999 mengenai Pemberian Pengelolaan Kawasan Hutan Dengan Tujuan Khusus. Penataan batas Kawasan Hutan dengan Tujuan Khusus (KHDTK) diatur lebih lanjut dalam Peraturan Menteri Kehutanan Nomor P.43/Menhut-II/2013 tanggal 19 Agustus 2013 (Wirya, 2015).

Dalam meningkatkan pemanfaatan areal hutan Pendidikan, Fakultas Kehutanan Unhas telah mengusulkan peningkatan statusnya menjadi Kawasan Hutan dengan Tujuan Khusus (KHDTK) dan disetujui oleh Menteri Kehutanan melalui Surat Keputusan No. 86/Menhut II/2005 tentang perubahan keputusan Dirjen Kehutanan No. 63/Kpts/BS/1/1980 Tanggal 31 Maret 1980 tentang penunjukan areal hutan seluas 1.300 ha sebagai hutan pendidikan menjadi kawasan hutan dengan tujuan khusus untuk Hutan Pendidikan Unhas.

Peningkatan statuta hutan pendidikan Unhas menjadi Kawasan Hutan Dengan Tujuan Khusus (KHDTK) untuk Hutan Pendidikan Unhas berdasarkan SK. Menteri Kehutanan No. SK 86/Menhut-II/2005, memberikian peluang yang sangat besar dalam rangka peningkatan kapasitas hutan pendidikan tersebut kedepan sebagai salah satu lokasi untuk pengembangan Tri Darma Perguruan Tinggi. Implikasi dari peningkatan statuta tersebut adalah pengelolaan hutan 
pendidikan Bengo-Bengo sepenuhnya menjadi tanggung jawab Fakultas Kehutanan UNHAS (Bachtiar, 2010).

Keberadaan hutan pendidikan sebagai laboratorium lapangan, mutlak diperlukan untuk mendukung kelancaran penyelenggaraan pendidikan kehutanan. Terlebih-lebih pada saat ini, sudah dapat dirasakan semakin sulit mencari lokasi untuk penyelenggaraan praktikum mata ajaran tertentu, dan penelitian bagi para siswa, mahasiswa dan penelitian. Oleh karena itu muncul berbagai gagasan yang mengarah kepada kemungkinan intensifikasi pengelolaan hutan pendidikan yang dapat memenuhi target yang diinginkan, bahkan bila memungkinkan dapat menjadi income generating unit untuk menopang kegiatan-kegiatan pendidikan lainnya. Untuk mengarah kepada keinginan tersebut, diperlukan perencanaan yang baik dan rasional serta didukung oleh berbagai pihak dan kebijakan-kebijakan yang terkait (Abbas, 2005).

Dari sudut pandang kebijakan, permasalahan mendasar dari segi implementasi kebijakan peraturan terhadap pengelolaan kawasan hutan pendidikan bengo-bengo adalah pertama mengenai pengaruh kebijakan yang dikeluarkan terhadap mekanisme pengelolaan. Kedua, pengaruh hubungan koordinasi pelaksana kebijakan peraturan terkait antar berbagai pihak. Ketiga, mengenai kepentingan secara langsung maupun tidak langsung dari berbagai stakeholder terkait.

Berdasarkan hal tersebut di atas, maka diperlukan analisis terkait kebijakan-kebijakan pemerintah pusat maupun daerah yang terkait dalam pengelolaan kawasan hutan dengan tujuan khusus, khususnya pada Hutan Pendidikan Unhas.

\section{METODE PENELITIAN}

\subsection{Tempat dan Waktu}

Penelitian dilaksanakan di Hutan Pendidikan Unhas, yang berada di Kabupaten Maros Provinsi Sulawesi Selatan. Penelitian ini dilaksanakan bulan April - Juli 2017.

\subsection{Alat dan Bahan}

Alat yang digunakan dalam penelitian ini adalah alat tulis, panduan wawancara, tape recorder dan kamera, sedangkan. Objek dalam penelitian ini adalah stakeholder yang terlibat dalam pengelolaan hutan pendidikan di Kabupaten Maros.

\subsection{Metode Pengambilan Data}

Metode penelitian yang digunakan dalam pengumpulan data yang diperlukan adalah:

\section{a. Pengumpulan Informasi dari Narasumber}

Data pokok dikumpulkan dengan wawancara semi-terstruktur, metode snowball dan penelusuran pustaka. Wawancara akan dilakukan dengan cara berdiskusi langsung dengan narasumber sesuai dengan panduan wawancara. Adapun panduan wawancara yang digunakan adalah panduan wawancara untuk instansi pemerintah dan non pemerintah). Wawancara dilanjutkan untuk mengetahui apabila ada stakeholder lain yang terlibat namun belum teridentifikasi. Data dan informasi yang berasal dari narasumber kedua dan selanjutnya digunakan untuk melengkapi data dan informasi dari narasumber awal. Metode penentuan narasumber di atas biasanya disebut snowball sampling (Wildemuth, 2016).

Narasumber yang menjadi sumber informasi dalam penelitian ini akan ditentukan sesuai dengan tujuan penelitian, yaitu mengetahui stakeholder yang terlibat dalam pengelolaan Hutan Pendidikan Unhas. Narasumber penelitian merupakan stakeholder yang dipilih dengan persyaratan tertentu yakni status sosial atau pekerjaan terkait dengan pengelolaan Hutan Pendidikan, mempunyai komitmen terhadap pengelolaan hutan pendidikan, terbuka dalam 
menerima pendapat narasumber lain bersedia mencari konsensus dan dapat menyetujui konsensus (diadaptasi dari Reed dkk., 2009). Narasumber merupakan narasumber kunci. Stakeholder dan institusi diklasifikasikan menurut hirarki pemerintahan yakni level desa/kecamatan, kabupaten dan provinsi yang dipilih secara sengaja (purvosive sampling) (Abbas 2005).

Narasumber yang dimaksud adalah key person dari masing-masing stakeholder, yaitu kepala dinas, direktur pengelola hutan pendidikan, dan kelompok masyarakat untuk mewakili stakeholder yang bersangkutan dalam memberikan informasi yang akurat mengenai stakeholder tersebut dalam hubungannnya dengan pengelolaan Hutan Pendidikan Unhas, untuk melihat sikap dan posisi masyarakat terhadap hutan pendidikan (Garnadi, 2004).

\section{b. Penggalian dokumen formal, dan analisisnya}

Data sekunder dikumpulkan dengan cara penelusuran dokumen kebijakan. Dokumen formal ini adalah antara lain dalam penelitian ini meliputi kebijakan terkait pengelolaan hutan pendidikan sebagai KHDTK, master plan Hutan Pendidikan Unhas (Fakultas Kehutanan Unhas, 2015), data kondisi umum Hutan Pendidikan Unhas, dokumen tentang program kerja/kegiatan, jumlah anggaran, jumlah sumberdaya manusia (SDM), jejaring kerja, dan dokumen lain yang diperlukan untuk menunjang penelitian. Pengambilan data penunjang dilakukan dengan penelusuran pustaka dan observasi lapang. Menganalisis kebijakan dan berita atau isu yang ada dalam mekanisme hubungan Hutan Pendidikan Unhas dengan berbagai pihak dalam pengelolaan hutan pendidikan dilakukan secara deskriptif dengan menggunakan analisis isi.

Analisis isi merupakan definisi mengenai isi kebijakan, mencakup maksud, tujuan, orientasi kebijakan dan implementasi dari kebijakan tersebut serta dampak dari kebijakan atau berita atau isu tersebut terhadap mekanisme hubungan Hutan Pendidikan Unhas dengan berbagai pihak dalam pengelolaannya.

Analisis isi kebijakan dan TUPOKSI yang dilakukan dalam penelitian ini menggunakan kata kunci (key word) berupa wisata, pengelolaan, pemanfaatan SDA, konservasi, partisipasi, ekonomi, insentif, dan dampak lingkungan. Selanjutnya juga dalam analisis kebijakannya mengadopsi refleksi efektifitas kebijakan dari Sabatier \& Mazmanian, 1979.

\section{c. Observasi Lapangan}

Observasi lapangan merupakan pengamatan langsung dan pencatatan secara teliti terhadap kajian yang diteliti. Observasi lapang dilakukan untuk mengetahui lokasi-lokasi dalam areal Hutan Pendidikan yang masih banyak digunakan/diakses oleh masyarakat, mengetahui implementasi kebijakan dan keterangan-keterangan yang didapatkan dari hasil wawancara.

\section{HASIL DAN PEMBAHASAN}

\subsection{Identifikasi Kebijakan Pemerintah Pusat dan Daerah dalam Pengelolaan Hutan Pendidikan Unhas}

a. Kebijakan Umum

\section{UU 41 Tahun 1999}

Undang-undang Nomor 41 Tahun 1999 merupakan aturan perundang-undangan di bidang kehutanan yang dijadikan sebagai dasar dan acuan dalam penyelenggaraan pengelolaan dan pemanfaatan kawasan hutan di Indonesia. Salah satu kebijakan yang diatur dalam undangundang ini adalah penetapan kawasan hutan tertentu dengan tujuan khusus (KHDTK). Beberapa aturan terkait KHDTK yang tercantum dalam naskah undang -undang Nomor 41 Tahun 1999 adalah sebagai berikut: 
BAB II terkait status dan fungsi hutan Pasal 8 Ayat 1 menjelaskan kewenangan pemerintah menetapkan kawasan tertentu dengan tujuan khusus. Selanjutnya, ayat 2 menjelaskan tujuan khusus yang dimaksud pada ayat 1 adalah tujuan yang merupakan keperluan umum seperti penelitian dan pengembangan, pendidikan dan pelatihan, serta religi dan budaya. Dalam penggunaanya, dijelaskan pada ayat 3 bahwa pengunaan kawasan hutan untuk tujuan khusus tidak mengubah fungsi pokok kawasan hutan.

BAB III terkait pengurusan hutan Pasal 10 Ayat 3 dijelaskan pada poin 2 bahwa pengurusan hutan yang bertujuan untuk memperoleh manfaat yang sebesar-besarnya serta serba guna dan lestari salah satunya meliputi kegiatan penelitian dan pengembangan, serta pendidikan dan pelatihan.

BAB $V$ bagian Ketiga terkait pemanfaatan hutan dan penggunaan kawasan hutan pada Pasal 34 menjelaskan bahwa pengelolaan kawasan hutan untuk tujuan khusus sebagaimana yang dijelaskan pada pasal 8 dapat diberikan salah satunya kepada lembaga Pendidikan dan lembaga penelitian.

\section{PP No. 34 Tahun 2002}

Selain aturan perundang-undangan, peraturan pemerintah Nomor 34 Tahun 2002 juga mengatur tata hutan dan penyusunan rencana pengelolaan, pemanfaatan, dan penggunaan kawasan hutan dengan tujuan khusus pada BAB I Pasal 4. Pasal 4 yang terdiri 4 ayat, 3 diantaranya membahas aturan terkait KHDTK diantaranya:

- Ayat 1 menjelaskan tentang penetapan oleh Menteri terkait tata hutan dan penyusunan rencana pengelolaan, pemanfaatan, dan penggunaan kawasan hutan dengan tujuan khusus dalam rangka untuk kepentingan penelitian, pengembangan, Pendidikan dan pelatihan kehutanan, serta religi dan budaya.

- Ayat 2 menjelaskan tentang penataan dan penyusunan rencana pengelolaan, pemanfaatan, dan penggunaan kawasan hutan dengan tujuan khusus sebagaimana dimaksud pada ayat 1 untuk kegiatan penelitian dan pengembangan diberikan kepada lembaga yang melaksanakan kegiatan penelitian dan pengembangan; untuk kegiatan Pendidikan dan pelatihan dapat diberikan kepada lembaga yang melaksanakan Pendidikan dan pelatihan.

- Ayat 3 menjelaskan tentang penataan dan penyusunan rencana pengelolaan, pemanfaatan, dan penggunaan kawasan hutan dengan tujuan khusus ditetapkan oleh Menteri.

\section{PP. No. 6 Tahun 2007 jo PP No. 3 Tahun 2008}

Peraturan pemerintah terkait legalitas penataan hutan sebagai kawasan hutan dengan tujuan khusus (KHDTK) tercantum pada PP. No. 6 Tahun 2007 jo PP No. 3 Tahun 2008. BAB III yang menjelaskan tentang tata hutan dan penyusunan rencana pengelolaan hutan pada Pasal 11 ayat 2 menjelaskan bahwa penetapan areal tertentu pada kawasan hutan oleh pemerintah sebagai hutan kemasyarakatan, hutan adat, hutan desa, dan kawasan hutan untuk tujuan khusus (KHDTK) Permenhut Nomor 16 Tahun 2014

Peraturan Menteri Kehutanan Nomor 16 Tahun 2014 terkait pedoman pinjam pakai kawasan hutan pada BAB I Bagian Kedua tentang ketentuan umum dijelaskan pada Pasal 8 tentang kawasan hutan dengan tujuan khusus (KHDTK) pada Ayat 1 bahwa Penggunaan kawasan hutan oleh pihak lain berupa jalan yang dibangun pemegang izin pemanfaatan hutan atau Perum Perhutani atau pengelola Kawasan Hutan Dengan Tujuan Khusus (KHDTK) atau pemegang izin pinjam pakai kawasan hutan dilakukan dengan skema penggunaan fasilitas bersama, tidak melalui pemberian izin pinjam pakai kawasan hutan. Selanjutnya, pada ayat 2 memperjelas bahwa skema penggunaan fasilitas Bersama dituangkan dalam perjanjian kerjasama. 


\section{PP Nomor 12 Tahun 2010}

Peraturan pemerintah yang mengatur terkait KHDTK pada PP No. 12 tahun 2010 tentang Penelitian dan Pengembangan, serta Pendidikan dan pelatihan kehutanan mencantumkan secara jelas terkait kawasan hutan dengan tujuan khusus pada BAB IV tentang penggunaan kawasan hutan dengan tujuan khusus untuk litbang dan diklat kehutanan pada Pasal 55 ayat 1 menjelaskan bahwa Lembaga litbang kehutanan dapat menggunakan kawasan hutan dengan tujuan khusus untuk keperluan litbang kehutanan setelah ditetapkan oleh Menteri. Sedangkan Pasal 56 Ayat 1 menjelaskan bahwa Kawasan hutan dengan tujuan khusus sebagaimana dimaksud dalam Pasal 55 dapat ditetapkan pada semua fungsi kawasan hutan kecuali pada cagar alam dan zona inti taman nasional. Pada ayat 2 terkait Kawasan hutan yang telah dibebani hak pengelolaan oleh BUMN dapat ditetapkan sebagai kawasan hutan dengan tujuan khusus dengan ketentuan tidak mengubah fungsi pokok kawasan hutan, serta pada ayat 3 menjelaskan bahwa dalam kawasan hutan yang telah dibebani izin pemanfaatan hutan, dapat ditetapkan sebagai kawasan hutan dengan tujuan khusus setelah dikeluarkan dari areal kerjanya.

\section{Permenhut No. P.43/Menhut-II/2013}

Peraturan Menteri Kehutanan yang mengatur terkait penataan batas kawasan hutan dengan tujuan khusus (KHDTK) tercantum pada Peraturan Menteri Kehutanan Nomor P.43/Menhut-II/2013 tentang Penataan Batas Areal Kerja Izin Pemanfaatan Hutan, Persetujuan Prinsip Penggunaan Kawasan Hutan, Persetujuan Prinsip Pelepasan Kawasan Hutan Dan Pengelolaan Kawasan Hutan Pada Kesatuan Pengelolaan Hutan Dan Kawasan Hutan Dengan Tujuan Khusus.

BAB II terkait Ruang Lingkup pada Pasal 3 mengenai penataan batas KHDTK yang batasnya sekaligus merupakan batas luar kawasan hutan dilaksanakan mengikuti tahapan tata batas kawasan hutan dengan disetujui oleh Panitia Penataan Batas, dan Pasal 4 yang batasnya sekaligus merupakan batas fungsi kawasan hutan dilaksanakan mengikuti tahapan penataan batas fungsi kawasan hutan dengan disetujui oleh Panitia Penataan Batas.

BAB III terkait Penataan Batas Areal Kerja menjelaskan terkait teknis pelaksanaan penataan batas KHDTK, mulai dari penyusunan rencana, penilaian dan pengesahan rencana, sampai pelaksanaan penataan batas. Tahapan pelaksanaan penataan batas areal kerja tercantum pada Pasal 5 ayat 2. Tim Pelaksana penataan batas KHDTK dijelaskan pada Pasal 8 ayat 2 bahwa pelaksanaan penataan batas dapat dilakukan oleh pemegang izin pemanfaatan hutan, persetujuan prinsip penggunaan kawasan hutan, persetujuan prinsip pelepasan kawasan hutan atau pengelolaan KPH dan KHDTK sendiri atau menunjuk rekanan pelaksana yang mempunyai kompetensi di bidang pengukuran dan pemetaan.

\section{b. Kebijakan Khusus}

\section{PP. Nomor 12 Tahun 2010}

Kebijakan yang melegalkan secara khusus terkait hutan Pendidikan Unhas tercantum pada Peraturan Pemerintah Nomor 12 Tahun 2010 tentang Penelitian dan Pengembangan, serta Pendidikan dan pelatihan kehutanan pada $B A B$ II terkait penyelenggaraan penelitian $\mathrm{dn}$ pengembangan di Bagian Kesatu Pasal 5 Ayat 1 menjelaskan bahwa penyelenggaraan litbang kehutanan selain Badan Litbang Kehutanan Kementerian dapat diselenggarakan oleh pemerintah provinsi, pemerintah kabupaten/kota, perguruan tinggi, dunia usaha, dan masyarakat.

\section{SK.86/MENHUT-II/2005}

Penunjukan kawasan hutan Pendidikan Unhas yang ditetapkan oleh Menteri melalui SK. 86/MENHUT-II/2005 


\subsection{Analisis Kebijakan}

Berdasarkan hasil pengamatan di lapangan melalui proses wawancara dengan pemerintah pusat, pemerintah provinsi, dan pemerintah kabupaten. Terdapat adanya persoalan dalam konsistensi dan sinkronasi kebijakan, salah satunya yaitu terkait tumpang tindih aktor penanggung jawab dalam pelaksanaan pengelolaan Hutan Pendidikan Unhas. Kawasan Hutan Pendidikan seluas 1.300 ha yang telah ditunjuk sebagai KHDTK masih memiliki fungsi utama sebagai Hutan Lindung, dimana yang bertanggung jawab dalam hal ini yaitu pihak Pemerintah Daerah melalui Dinas Kehutanan. Hal ini dapat dilihat antara lain pada Tabel 1.

Pemerintah Daerah merasa masih memiliki tanggung jawab dalam pengelolaan, karena dalam SK. 86/MENHUT-II/2005 yaitu SK penunjukan pengelola Hutan Pendidikan tidak dirincikan mengenai tugas pokok, fungsi dan tanggung jawab, serta batasan-batasan dalam pengelolaannya. Kawasan Hutan Pendidikan dengan fungsi utama Hutan Lindung masih juga menjadi tanggung jawab Dinas Kehutanan. Dinas Kehutanan juga yang bertanggung jawab dalam memberikan keterangan jika terjadi permasalahan di KHDTK tersebut.

Sementara dalam beberapa hal seperti penataan batas, pihak Dinas Kehutanan yang merasa memiliki tanggung jawab penuh untuk mengatur hal tersebut. Selain itu dalam penerbitan dokumen pengangkutan, dan produksi hasil hutan harus melalui Pemerintah Daerah dalam hal ini Dinas Kehutanan.

Maka dari itu perlu adanya kebijakan Menteri terkait KHDTK yang membunyikan bahwa tanggung jawab sepenuhnya terhadap kawasan tersebut adalah pengelola pihak pengelola KHDTK dengan rincian tugas pokok, fungsi, dan segala bentuk teknis pengelolaan tercantum dalamnya. Sehingga pihak Pemerintah Daerah hanya tinggal menerima rencana kerja pengelolaan dan laporan tahunan dari pihak pengelola agar terbangun persepsi bersama dalam pengelolaan KHDTK.

\subsection{Implementasi Kebijakan}

Kriteria efektifitas implemetasi kebijakan berdasarkan data hasil temuan lapangan serta data sekunder adalah sebagai berikut:

a. Tujuan yang dicapai sesuai dengan target pemerintah

Hasil temuan lapangan menunjukkan bahwa kebijakan yang berlaku saat ini yakni pada sektor kehutanan, seluruh kekuasaan dan wewnang dilimpahkan ke Dinas Kehutanan Provinsi, sehingga akan lebih sulit untuk menilai adanya hubungan antara target capaian pemerintah daerah dengan rencana kerja pihak pengelola KHDTK. Sejauh ini rencana kerja pengelolaan KHDTK hanya disusun dan dilaksanakan berdasarkan kebutuhan pendidikan dan penelitian baik dalam lingkup kampus Unhas maupun dari adanya bentuk kerjasama dengan pihak lain dalam hal penelitian dan pengembangan. Kebijakan khusus yang mencantumkan bagaimana rencana kerja pengelolaan KHDTK disusun, sampai ke tahap pelaporan, dan aturan teknis terkait hal tersebut sampai saat ini belum ada peraturan perundangan yang mengatur hal tersebut. 

品
Jurnal Hutan dan Masyarakat. Vol. 9 (2): 114-122, Desember 2017
Diserahkan: 2017-12-04; Diterima: 2017-12-27
ISSN: 1907-5316. ISSN ONLINE: 2613-9979

Tabel 1. Hasil Identifikasi Kebijakan Kawasan Hutan dengan Tujuan Khusus (KHDTK)

\begin{tabular}{|c|c|c|c|c|c|}
\hline Aturan Perundangan & Perencanaan & Pengelolaan & Pemanfaatan & Konservasi & Partisipasi \\
\hline \multirow{3}{*}{ UU. No. 41 Tahun 1999} & \multirow[t]{3}{*}{ Pasal 8 ayat 1} & Pasal 8 ayat 2 & Pasal 8 ayat 2 & \multirow[t]{3}{*}{ Pasal 8 ayat 3} & \\
\hline & & Pasal 10 ayat 3 & \multirow[t]{2}{*}{ Pasal 10 ayat 3} & & \\
\hline & & Pasal 34 & & & \\
\hline PP 34 tahun 2002 & BAB 1 Pasal 4 ayat 1,3 & BAB 1 Pasal 4 ayat 2 & BAB 1 Pasal 4 ayat 2 & Pasal 10 ayat 3 & \\
\hline $\begin{array}{l}\text { PP. No. } 6 \text { Tahun } 2007 \text { jo PP } \\
\text { No. } 3 \text { Tahun } 2008\end{array}$ & BAB III Pasal 11 Ayat 2 & & & & \\
\hline $\begin{array}{l}\text { Permenhut Nomor } 16 \text { Tahun } \\
2014\end{array}$ & & Pasal 8 Ayat 1,2 & & & \\
\hline $\begin{array}{l}\text { Permenhut No. P.43/Menhut- } \\
\text { II/2013 }\end{array}$ & BAB III Pasal 6 dan Pasal 7 & & & & \\
\hline PP Nomor 12 Tahun 2010 & $\begin{array}{l}\text { Pasal } 56 \text { Ayat 3, BAB V Pasal } 5 \\
\text { Ayat } 1\end{array}$ & BAB IV Pasal 55 Ayat 1 & $\begin{array}{l}\text { BAB IV Pasal } 55 \text { Ayat } \\
1\end{array}$ & Pasal 56 Ayat 1,2 & $\begin{array}{l}\text { BAB V Pasal } 5 \text { Ayat } \\
1\end{array}$ \\
\hline
\end{tabular}


b. Kemampuan manejerial dan kemauan politik implementasi dari beberapa staf kunci KHDTK Berdasarkan hasil temuan lapangan, staf kunci KHDTK telah melakukan berbagai aktivitas kerjasama dengan beberapa pihak, namun pada level tapak dalam hal ini masyarakat sekitar KHDTK maupun aparatur desa/kecamatan, staff kunci KHDTK belum melakukan koordinasi yang cukup baik dalam membangun koordinasi dan jejaring dalam pengelolaan KHDTK, dan masyarakat tidak sepenuhnya memperlakukan hutan pendidikan sebagai barang common (sebagaimana syarat barang common oleh Arnold, 1998).

Saat ini pihak pengelola membangun kerjasama dengan pemerintah pusat dalam hal ini Balai Perbenihan Tanaman Hutan (BPTH) dalam hal pembangunan kebun benih, kerjasama dalam bidang penelitian (marker genetik, dan kultur jaringan), selain itu juga membangun kerjasama dengan Balai Perhutanan Sosial dan Kemitraan Lingkungan (BPSKL) dalam upaya mendorong perhutanan sosial di Hutan Pendidikan melalui skema Kemitraan Kehutanan (sebagaimana prinsip kolaborasi dalam Darusman, 2008 serta Rahardjo dan Kahathur, 2006).

Pihak pengelola dapat mengambil inisiatif dalam melaksanakan rencana kerja dengan turut melibatkan masyarakat sekitar kawasan hutan, sehingga dapat berpotensi memberikan dampak ekonomi terhadap masyarakat (seperti Affandi dkk, 2017). Hal ini juga dimaksudkan untuk mengurangi potensi konflik yang akan terjadi jika pihak pengelola Hutan Pendidikan terus mengeksklusifkan diri tanpa mempertimbangkan kehadiran masyarakat sekitar kawasan hutan yang telah ada jauh sebelum ditetapkannya kawasan tersebut sebagai KHDTK. Hal ini penting sebagai bagian dari fungsi tata kelola konflik (Fisher dkk, 2017). Walaupun pada awalnya harus melewati tahap adaptasi antara pihak-pihak kunci (Kusumanto, 2006; Dhiaulhaq dkk., 2017)

c. Tingkat dukungan oleh aktor kunci seperti parlemen, tokoh, dan masyarakat

Pemerintah Pusat dalam hal ini Kementerian Lingkungan Hidup dan Kehutanan (KLHK) memiliki tingkat partisipasi yang cukup tinggi dalam pengelolaan Hutan Pendidikan. Balai Perbenihan Hutan Tanaman (BPTH) memberi insntif berupa bantuan staf dalam upaya mengembangkan kebu benih yang ada dalam kawasan Hutan Pendidikan, sementara Balai Perhutanan Sosial dan Kemitraan Lingkungan (BPSKL) berkomitmen akan memberikan bantuan baik berupa peralatan maupun tenaga kerja dalam upaya pemberdayaan masyarakat sekitar hutan apabila telah terbit Nota Kesepakatan Kerjasama (NKK) Kemitraan Kehutanan dalam kawasan Hutan Pendidikan, sebagaimana disebuttkan oleh Munggoro dan Dani, 2002 serta Gujja, 1999 bahwa kemitraan adalah dapat menjadi wadah dalam mengelola bersama. Kemitraan ini juga merupakan skema resmi Perhutaan Sosial di Indonesia (Moeliono dkk., 2017)

Pemerintah Provinsi maupun Kabupaten belum menaruh perhatian khusus terhadap pengelolaan KHDTK Hutan Pendidikan Universitas Hasanuddin. Hal ini terlihat dari kurangnya informasi yang bisa diberikan terkait Hutan Pendidikan yang mengindikasikan bahwa KHDTK ini belum tercantum sebagai program strategis pemerintah provinsi/daerah.

\section{KESIMPULAN DAN SARAN}

Kebijakan yang diperlukan dalam pengelolaan Kawasan Hutan Dengan Tujuan Khusus (KHDTK) adalah kebijakan dengan tidak menimbulkan persepsi bahwa adanya tumpang tindih antar penanggung jawab dalam aktivitas pengelolaan kawasan, kebijakan yang mengatur secara jelas dan rinci terkait aturan-aturan teknis dalam pelaksanaan pengelolaan kawasan, tidak adanya ego sektoral atau ego kelembagaan antara masing-masing pembuat kebijakan. Perlu diperhatikan bahwa kawasan yang telah ditetapkan sebagai KHDTK masih memiliki fungsi utama, baik itu fungsi lindung, produksi, maupun konservasi, sehingga masih dapat menimbulkan persepsi yang berbeda 
dalam melihat siapa yang akan menjadi penanggung jawab pada kawasan tersebut. Untuk itu perlu adanya peraturan perundangan yang menjelaskan terkait peran masing-masing pihak, serta apa saja yang menjadi tugas pokok fungsi, serta wewenang nya dalam pengelolaan KHDTK. Selain itu perlu juga adanya peraturan yang mengatur terkait teknis pengelolaan, yang juga mengatur bagaimana mekanisme penyusunan rencana kerja pengelolaan KHDTK, sampai ke tahap pelaporan kerja tahunan pengelola KHDTK, serta bagaimana koordinasi, komunikasi, dan peran masing-masing terkait pembuatan, pelaksanaan, monitoring, evaluasi, dan pelaporan rencana kerja pengelolaan KHDTK.

\section{DAFTAR PUSTAKA}

Abbas, R. 2005. Mekanisme Perencanaan Partisipasi Stakeholder Taman Nasional Gunung Rinjani [Tesis]. Sekolah Pasca Sarjana Pertanian Bogor.

Affandi, O., Zaitunah, A., \& Batubara, R. (2017). Potential Economic and Development Prospects of Non Timber Forest Products in Community Agroforestry Land around Sibolangit Tourism Park. Forest and Society, 1(1), 68-77. doi:http://dx.doi.org/10.24259/fs.v1i1.1096

Arnold JEM. 1998. Managing Forest as Common Property. Rome: FAO

Darusman, D. 2008. Menguatkan Kolaborasi PHBM. Duta Rimba 24(3):28-30.

Dhiaulhaq, A., Wiset, K., Thaworn, R., Kane, S., \& Gritten, D. (2017). Forest, water and people: The roles and limits of mediation in transforming watershed conflict in Northern Thailand. Forest and Society, 1(2),121-136. doi:http://dx.doi.org/10.24259/fs.v1i2.2049

Fakultas Kehutanan Unhas, 2015. Profil Hutan Pendidikan Universitas Hasanuddin. Laporan.

Fisher, L., Kim, Y., Latifah, S., \& Mukarom, M. (2017). Managing Forest Conflicts: Perspectives of Indonesia's Forest Management Unit Directors. Forest and Society, 1(1), 8-26. doi:http://dx.doi.org/10.24259/fs.v1i1.772

Garnadi, D. 2004. Pengetahuan, Sikap dan Tindakan Masyarakat Sekitar Hutan terhadap Hutan. Tesis. Sekolah Pascasarjana IPB. Bogor.

Gujja, B. (1999). Partnerships for protection: new strategies for planning and management for protected areas. Earthscan

Kusumanto, T., Yuliani, E. L., Macoun, P., Indriatmoko, Y., \& Adnan, H. (2006). Belajar beradaptasi: bersama-sama mengelola hutan di Indonesia. CIFOR.

Moeliono, M., Thuy, P., Waty Bong, I., Wong, G., \& Brockhaus, M. (2017). Social Forestry - why and for whom? A comparison of policies in Vietnam and Indonesia. Forest and Society, 1(2), 78-97. doi:http://dx.doi.org/10.24259/fs.v1i2.2484

Munggoro, Dani W. 2002. Manajemen Kemitraan: Meretas Kemelut Kawasan Koservasi di dalam: Prosiding Seminar Pemberdayaan Aset Perekonomian Rakyat Melalui Strategi Kemitraan dalam Mengelola Sumberdaya di Kabupaten Jember. Bogor: Pustaka Latin.

Rahardjo, B dan Kahathur, S.U. 2006. Kolaborasi Sebuah Solusi. Di dalam: Pengelolaan Hutan Berbasis Masyarakat. Departemen Kehutanan RI. hlm 49-79.

Reed M.S, Graves A, Dandy N, Posthumus H, Hubacek K, Morris J, Prell C, Quinn CH, Stringer LC. 2009. Who's and why? A typology of stakeholder analysis methids for natural resource management. Journal of Environmental Management 90:1933-1949.

Sabatier, P, \& Mazmanian, D. 1979. The Conditions Of Effective Implementation: A Guide to Accomplishing Policy Objectives. Policy analysis, 481-504.

Wildemuth, B. M. (Ed.). (2016). Applications of social research methods to questions in information and library science. ABC-CLIO. 